\title{
SURGICAL MANAGEMENT OF POST LIVING DONOR LIVER TRANSPLANTATION BILIARY COMPLICATIONS
}

\author{
George Magdy Halim Refaat Refaat Kamel, Mohammed Fathy Abd El-Ghafar \\ Hany Rafik Yowakim Ahmed Abd Elrazek Khalil
}

\begin{abstract}
Department of General Surgery, Faculty of MedicineAin Shams University Corresponding Author: George MagdyHalim Email: joo_7889@hotmail.com

Mob. +201000222942

Received: 29/8/2020

Accepted: 15/9/2020

Online ISSN: 2735-3540

Background: Biliary tract complications are the most common complications after liver transplantation and it remains a major source of morbidity in liver transplant patients. Non-operative treatment is often successful in early complications. Late complications presenting with leaks and obstruction are often more difficult to treat non-operatively and frequently require surgical treatment or re-transplantation. Some centers are more aggressive with management of biliary strictures and prefer early surgical intervention as opposed to multiple endoscopic dilations.

Aim of the work: The aim of this study is to, discuss the surgical management of post-transplant biliary complications and its outcome and rate of success with or without previous non-surgical methods in the postoperative follow up.

Patients and methods: This is a combined prospective and retrospective study conducted in DAR EL FOAD hospital, liver transplantation unitduring the period from 2011 till 2020. it included patient with post-transplant biliary complications who underwent surgical intervention with and without prior conservative trials. the study contains 14 patients who had failed non operative management. We discussed the surgical management and its outcome.

Results: 380 patients underwent liver transplantation during this period. 45 had biliary complications, of them 31 patients were managed by non-surgical measures and those were excluded from our study. 14 patients underwent surgical intervention. we had 4 patients with stricture, 7 patients with leakage and 3 patients with stricture and leakage. two patient had recurrent biliary complications after surgery and there was only one mortality.

Conclusion: Non-surgical measures are the primary treatment option for post transplantation biliary complications, but surgical management is the definite management for refractory cases with less hospital stay and recurrent admissions.
\end{abstract}

Keywords: liver transplantation, biliary complication, stricture, leakage

\section{INTRODUCTION:}

Liver transplantation has become a wellestablished treatment for end stage liver disease. Living donor liver transplant (LDLT) is still the predominant form for transplantation in Egypt. ${ }^{[1]}$

The postoperative course in liver transplantation patients ranges from straight forward to extremely complicated, and the 
outcome depends on the status of the recipient, donor organ, and technical issues in the operation. Complications after liver transplantation can have a significant impact on outcomes and costs of the procedure. Timely diagnosis of alterations in the normal postoperative course is the critical factor to minimize morbidity and mortality and to improve outcomes. ${ }^{[2]}$

Postoperative complications include, vascular complications as hepatic artery or portal vein stenosis or thrombosis, biliary complications as anastomotic stricture or leakage, graft rejections which may be acute or chronic rejections and other complications as bleeding, infection or encephalopathy. ${ }^{[3]}$

Biliary tract complications are the most common complications after liver transplantation. These complications are encountered more commonly as a result of increased number of liver transplantations and the prolonged survival of transplant patients. ${ }^{[4]}$

Non-operative treatment is often successful in early complications. Late complications presenting with leaks and obstruction are often more difficult to treat non-operatively and may require surgical treatment or re-transplantation. ${ }^{[5]}$

Anastomotic bile leaks after liver transplants in both Duct to duct anastomosis (DD) and Roux-en-Y Hepaticoje junostomy (RYHJ) with failed non operative management are managed surgically. Treatment may include the surgical revision of an anastomosis or the conversion of a DD to a RYHJ. Small anastomotic leaks after liver transplants can be managed with endoscopic stenting (DD) and PTC stenting with an internal-to-external drain (RYHJ). ${ }^{[6]}$

\section{AIM OF THE WORK:}

The aim of this study is to, discuss the surgical management of post-transplant biliary complications and its outcome and rate of success with or without previous nonsurgical methods in the postoperative follow up.

\section{PATIENTS AND METHODS:}

This was a combined prospective and retrospective study conducted in DAR EL FOAD hospital, liver transplantation unit during the period from 2011 till 2020.

Group of patients; patient with posttransplant biliary complications undergoing surgical intervention with and without prior conservative trials.

Inclusion criteria: Adult or pediatric male or female patients. Patients with biliary complications either leakage or stricture post-transplant. Patients with early and late biliary complications. Patient with failed conservative and interventional radiology methods.

Exclusion criteria: Patient refusal. Patients with biliary complications treated with conservative methods.

All patients will be subjected to the following:

Pre transplantation assessment for the Recipient: Full clinical history; personal history, present history, past history of any medical disorder. Full clinical examination; vital signs, body examination. Routine preoperative investigations including, complete blood count, random blood sugar, liver function test, bilirubin level, kidney function test, coagulation profile, blood gases. Pelvis abdominal ultrasound, MRCP and portal vein and hepatic artery duplex. Preoperative co-morbid factors such as hypertension, Diabetes mellitus or electrolyte disturbance, bilirubin nephropathy or encephalopathy will be controlled when possible before surgery

Post transplantation assessment of the Recipient: Patient follow up is done first in 
ICU where strict monitoring is done and if he/she is stable vitally and surgically, patient can be discharged from ICU to the transplantation unit where strict monitoring and follow up is done before patient can leave the hospital.

Monitoring of patient postoperatively include: -vital signs include pulse, blood pressure and temperature. Complexion of patient including pallor, cyanosis or jaundice. Laboratory follow up including liver functions, kidney functions, bilirubin level, CBC, coagulation profile, blood gases and lactate level. If any abnormalities appear as fever or jaundice or bile in drains or patient become toxic with increase leucocytic count, elevated serum bilirubin or dramatic increase in liver enzymes, so further investigations and imaging should be done as: Pelvi abdominal ultrasound or Pelvi-abdominal CT for any intra-abdominal collections. -MRCP for imaging of biliary tree in case of suspecting biliary complications as leakage or stricture. Hepatic artery and Portal vien duplex in case of suspecting ischemia or thrombosis. Liver biopsy in case of suspecting graft rejection.

Management of biliary complications: Biliary complications being the most common complications postoperatively after transplantation, are first managed conservatively either by external drainage (pig tail) or internal drainage by ERCP or PTC.

Surgical intervention is considered in: Failure of repeated endoscopic or percutaneous conservative measures. Multiple strictures in biliary tract. Biliary stricture due to ischemia of duct. Secondary biliary cirrhosis.

Surgical intervention in case of post transplantation biliary complication includes: Surgical drainage of intraabdominal collections that is hard to drained percutaneously. Revision of previous biliary anastomosis. Conversion of duct to duct anastomosis into bilio-enteric anastomosis. Re-transplantation in case of recurrence of sclerosing cholangitis or severe secondary biliary cirrhosis.

\section{Data collection:}

Data was collected from patient records, medical files, and interviews.

\section{Statistical analysis:}

The data was collected, tabulated and statistically analyzed. Description of quantitative variable was done as mean and standard deviation, and qualitative data as frequency. Fisher exact test was used to compare the groups as regard qualitative variable. One way Anova test was used to compare two groups as regard quantitative variable in parametric data. The results was considered significant(S) with $\mathrm{P}<0.05 \quad \&$ highly significant (HS) with $\mathrm{P}<0.01 . \mathrm{P} \geq 0.05$ will be considered non-significant (NS). Analysis of data will be done using IBM SPSS software (statistical program for social science version 21).

\section{RESULTS:}

Table 1 Patient demographic data.

\begin{tabular}{|l|c|}
\hline \multicolumn{1}{|c|}{ Variable } & Outcome \\
\hline Gender & \\
\hline Male & $11(78.6 \%)$ \\
\hline Female & $3(21.4 \%)$ \\
\hline Age & $44.93 \pm 9.25$ \\
\hline mean \pm SD & $28-58$ \\
\hline Range & \\
\hline BMI & $26.71 \pm 3.29$ \\
\hline mean \pm SD & $18-30$ \\
\hline Range & \\
\hline Complication & $4(28.57 \%)$ \\
\hline Stricture & $7(50 \%)$ \\
\hline Leakage & $3(21.43 \%)$ \\
\hline Stricture+leakage
\end{tabular}

Total transplanted patients were 380 patients, $45(11.84 \%)$ patients had postoperative biliary complications. 31 (68.9\%) patients were managed successfully by nonsurgical techniques and those patients were excluded from our study. 14 (31.1\%) 
patients were managed surgically and those patients were discussed in our study.

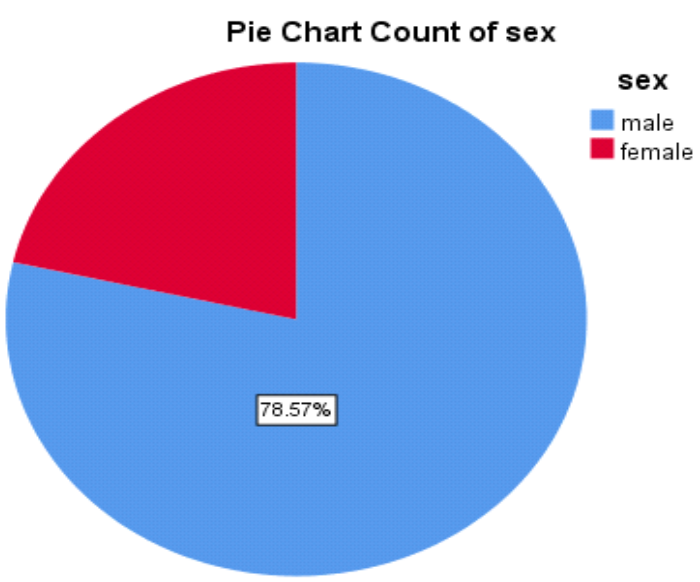

Figure 1 patient's sex

Table 2 Comorbidities

\begin{tabular}{|l|c|}
\hline \multicolumn{1}{|c|}{ Variable } & Outcome \\
\hline DM & \\
\hline Yes & $3(21.4 \%)$ \\
\hline No & $11(78.6 \%)$ \\
\hline Cause of cirrhosis & \\
\hline HCV & $11(78.6 \%)$ \\
\hline HBV & $1(7.1 \%)$ \\
\hline Autoimmune & $1(7.1 \%)$ \\
\hline Cryptogenic & $1(7.1 \%)$ \\
\hline
\end{tabular}

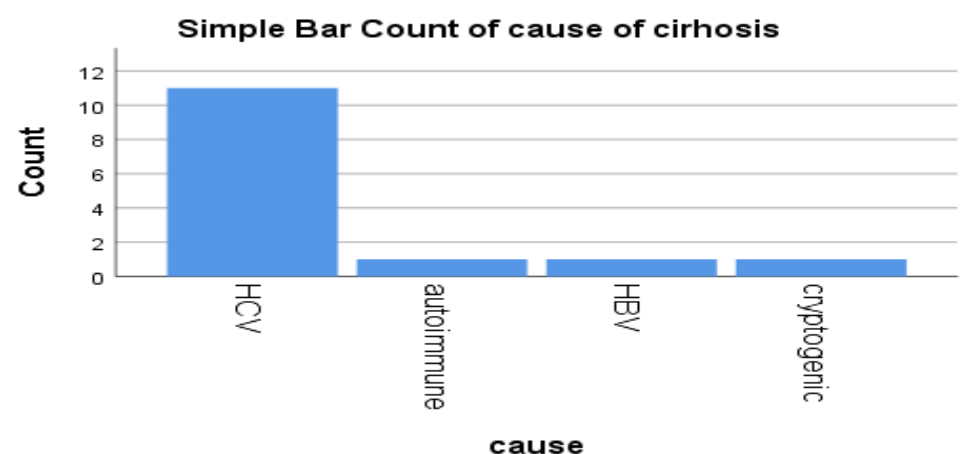

Figure 2 Cause of cirhosis

Table 3 Complications and demographic data

\begin{tabular}{|c|c|c|c|c|c|}
\hline & & $\begin{array}{l}\text { Stricture } \\
\text { (4) }\end{array}$ & $\begin{array}{c}\text { Leakage } \\
(7)\end{array}$ & $\begin{array}{c}\text { Stricture+leakage } \\
\text { (3) }\end{array}$ & $\mathrm{P}$ value \\
\hline Age & mean \pm SD & $42.50 \pm 11.39$ & $48.85 \pm 7.08$ & $39.00 \pm 9.64$ & 0.268 \\
\hline \multirow[t]{2}{*}{ Sex } & Male & $3(75 \%)$ & $7(100 \%)$ & $1(33.3 \%)$ & \multirow[b]{2}{*}{0.047} \\
\hline & Female & $1(25 \%)$ & $0(0 \%)$ & $2(66.7 \%)$ & \\
\hline \multirow[t]{2}{*}{ DM } & Yes & $0(0 \%)$ & $2(28.6 \%)$ & $1(33.3 \%)$ & \multirow[b]{2}{*}{0.538} \\
\hline & No & $4(100 \%)$ & $5(71.4 \%)$ & $2(66.7 \%)$ & \\
\hline \multirow[t]{4}{*}{ Cause of cirrhosis } & $\mathrm{HCV}$ & $3(75 \%)$ & $6(85.7 \%)$ & $2(66.7 \%)$ & \multirow{4}{*}{0.500} \\
\hline & $\mathrm{HBV}$ & $0(0 \%)$ & $1(14.3 \%)$ & $0(0 \%)$ & \\
\hline & Autoimmune & $0(0 \%)$ & $0(0 \%)$ & $1(33.3 \%)$ & \\
\hline & Cryptogenic & $1(25 \%)$ & $0(0 \%)$ & $0(0 \%)$ & \\
\hline
\end{tabular}


Table 3 shows the relation between different biliary complications and patients demographic data and cause of cirrhosis.

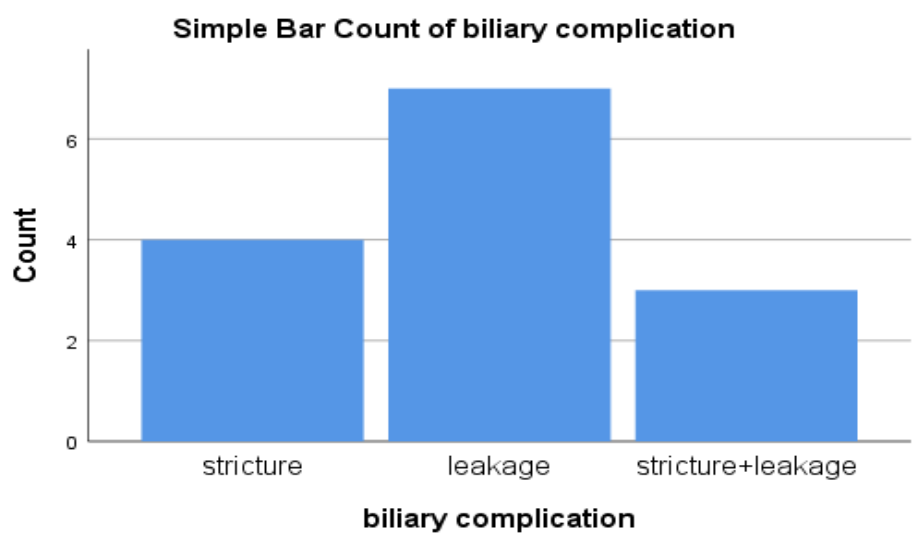

Figure 3 cases in each complication

Table 4 complication and previous transplantation data

\begin{tabular}{|c|c|c|c|c|c|}
\hline & & $\begin{array}{l}\text { Stricture } \\
\text { (4) }\end{array}$ & $\begin{array}{l}\text { Leakage } \\
\text { (7) }\end{array}$ & $\begin{array}{l}\text { Stricture+leakage } \\
\text { (3) }\end{array}$ & $\mathrm{P}$ value \\
\hline \multirow[t]{2}{*}{ No of ducts } & Single & $3(75 \%)$ & $2(28.6 \%)$ & $2(66.7 \%)$ & \multirow[t]{2}{*}{0.388} \\
\hline & Multiple & $1(25 \%)$ & $5(71.4 \%)$ & $1(33.3 \%)$ & \\
\hline \multirow[t]{3}{*}{ Hepatic artery } & Patent & $3(75 \%)$ & $4(57.1 \%)$ & $3(100 \%)$ & \multirow{3}{*}{0.874} \\
\hline & Stenosis & $0(0 \%)$ & $1(14.3 \%)$ & $0(0 \%)$ & \\
\hline & Thrombosis & $1(25 \%)$ & $2(28.6 \%)$ & $0(0 \%)$ & \\
\hline Cold ischemia time & mean \pm SD & $57.50 \pm 9.57$ & $55.00 \pm 5.00$ & $51.67 \pm 10.41$ & 0.620 \\
\hline Hot ischemia time & mean \pm SD & $46.25 \pm 4.79$ & $47.86 \pm 7.56$ & $65.00 \pm 27.84$ & 0.169 \\
\hline \multirow[t]{2}{*}{ Time for complication } & Early & $0(0 \%)$ & $5(71.4 \%)$ & $2(66.7 \%)$ & \multirow[t]{2}{*}{0.086} \\
\hline & Delayed & $4(100 \%)$ & $2(28.6 \%)$ & $1(33.3 \%)$ & \\
\hline
\end{tabular}

Table 4 shows the relation between 1ry transplantation data and complications, it shows that leakage occur more in multiple ducts (5 patients) and stricture occurs more in single duct (3 patients), but these differences were statistically in significant with $\mathrm{p}$ value $=0.388$. also there was no significant difference in hepatic artery abnormalities, cold and hot ischemia time with $p$ value $(0.874,0.620,0.169)$. also we can see that leakage occurred early mainly (in 5 patients) while stricture occurred late (in 4 patients) but these results were statistically insignificant with $\mathrm{p}$ value $=$ 0.086 . 
George Magdy Halim, et al.

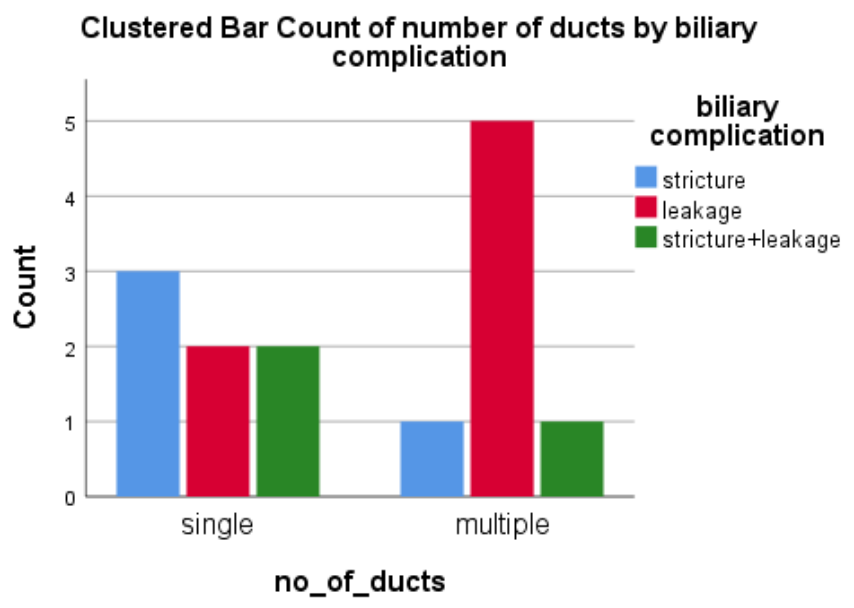

Figure 4 number of ducts in each complication

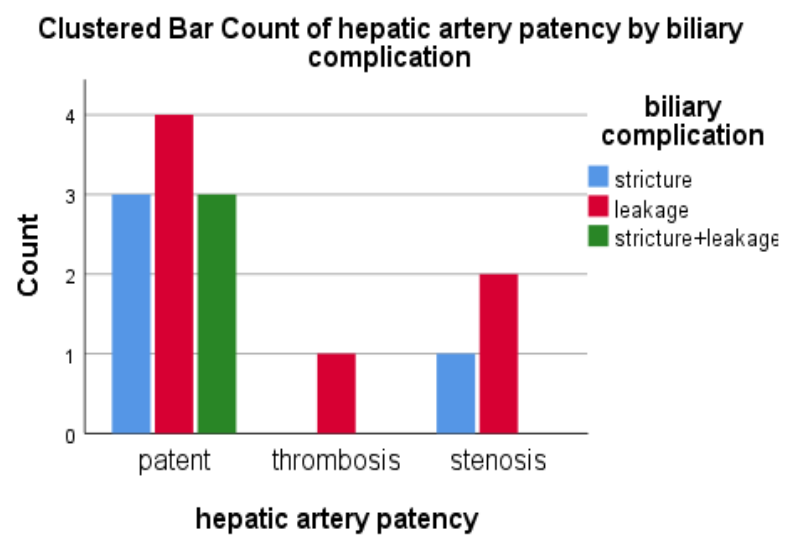

Figure 5 hepatic artery abnormalities in each complication

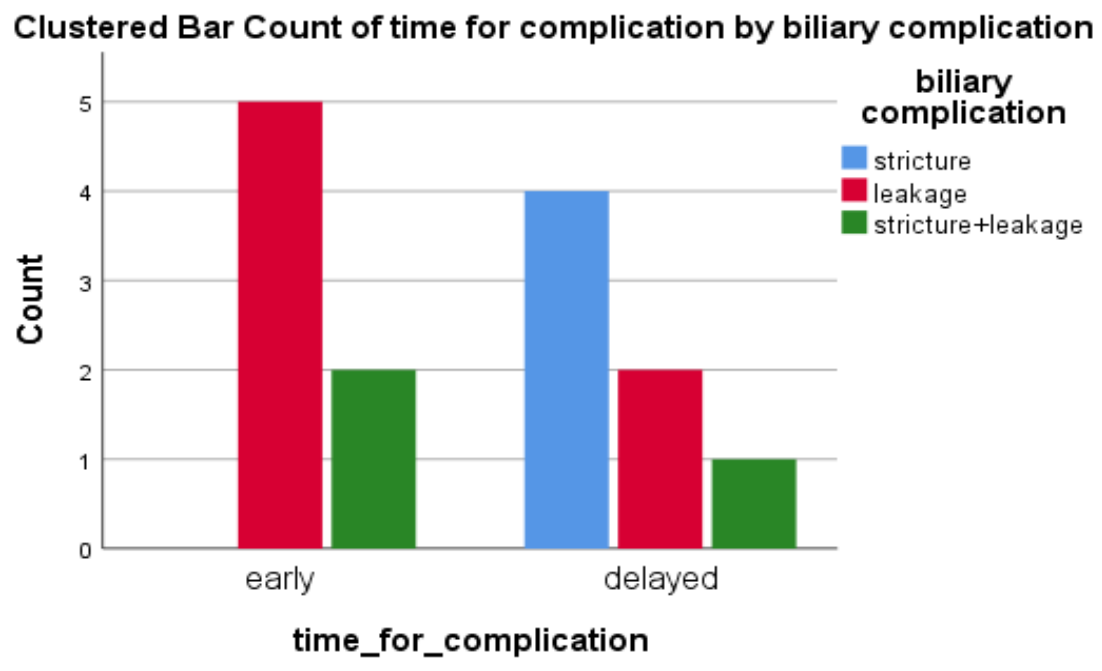

Figure 6 time to develop complication 
Table 5 non surgical management

\begin{tabular}{|l|l|l|l|l|l|}
\hline & & $\begin{array}{l}\text { Stricture } \\
(4)\end{array}$ & $\begin{array}{l}\text { Leakage } \\
(7)\end{array}$ & $\begin{array}{l}\text { Stricture+leakage } \\
(3)\end{array}$ & P value \\
\hline Pig tail & Yes & $0(0 \%)$ & $3(42.9 \%)$ & $0(0 \%)$ & \multirow{2}{*}{0.250} \\
\hline & No & $4(100 \%)$ & $4(57.1 \%)$ & $3(100 \%)$ & \\
\hline ERCP & Yes & $3(75 \%)$ & $3(42.9 \%)$ & $3(100 \%)$ & 0.371 \\
\hline & No & $1(25 \%)$ & $4(57.1 \%)$ & $0(0 \%)$ & \multirow{2}{*}{1.000} \\
\hline PTC & Yes & $0(0 \%)$ & $1(14.3 \%)$ & $1(33.3 \%)$ & \\
\hline & No & $4(100 \%)$ & $6(85.7 \%)$ & $2(66.7 \%)$ & \\
\hline
\end{tabular}

Table 5 shows the previous non-surgical management done in eachcomplication.

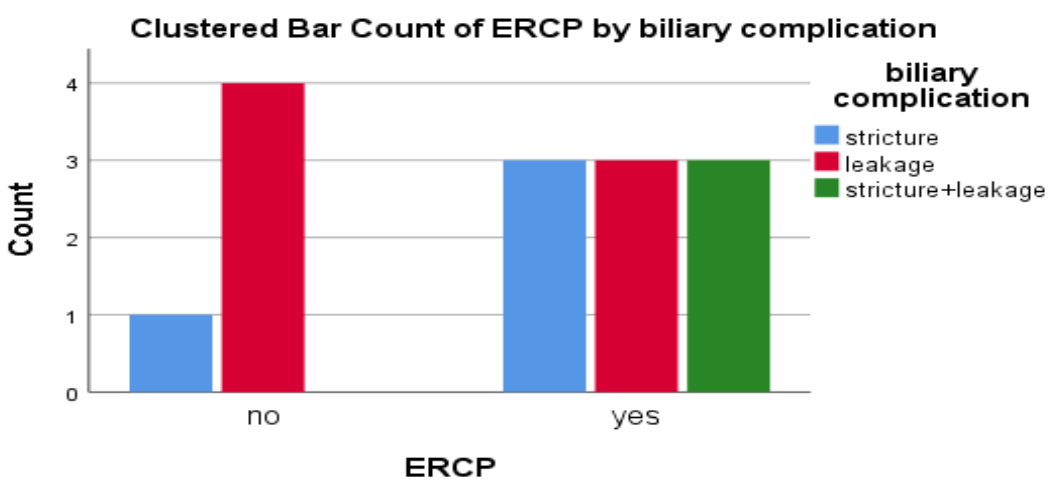

Figure 7 ERCP trial in each complication

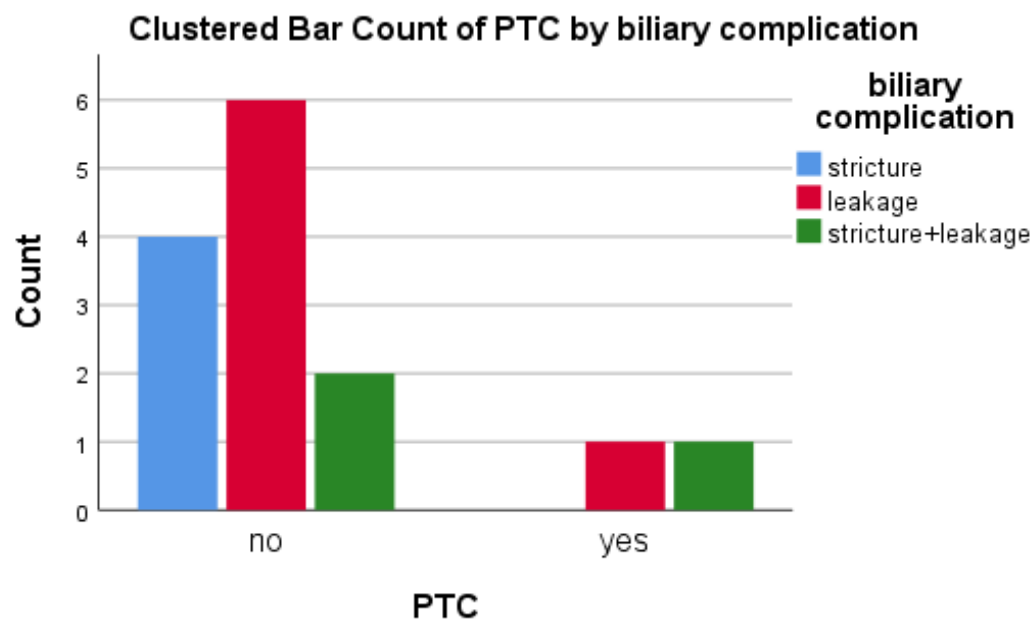

Figure 8 PTC trial in each complication

Table 6 surgical intervention and operative andpost operative data

\begin{tabular}{|l|l|l|l|l|l|}
\hline & & stricture & Leakage & Stricture+leakage & P value \\
\hline $\begin{array}{l}\text { Surgical } \\
\text { intervention }\end{array}$ & Drainage & $0(0 \%)$ & $4(57.1)$ & $0(0 \%)$ & \multirow{2}{*}{0.076} \\
& hepaticojejuonstomy & $4(100 \%)$ & $2(28.6 \%)$ & $3(100 \%)$ & \\
\hline & Repair + stenting & $0(0 \%)$ & $1(14.3 \%)$ & $0(0 \%)$ & \\
\hline & Opean \pm SD & $141.25 \pm 15.48$ & $109.29 \pm 19.46$ & $131.67 \pm 10.41$ & 0.030 \\
\hline Hospital stay & mean \pm SD & $22 \pm 3.74$ & $28 \pm 4.83$ & $38.67 \pm 28.94$ & 0.282 \\
\hline
\end{tabular}

Table 6 shows the surgical intervention and operative time in biliary complication surgery. 
George Magdy Halim, et al.

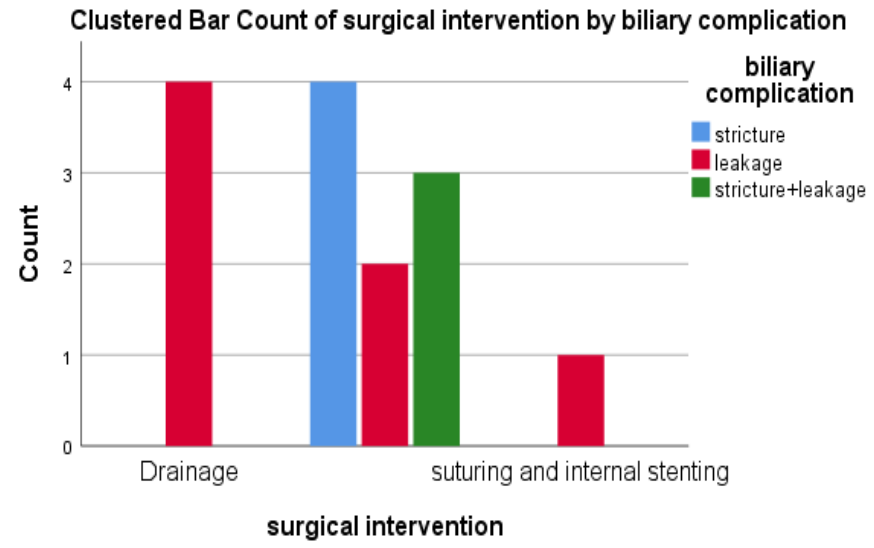

Figure 9 surgical intervention in each complication

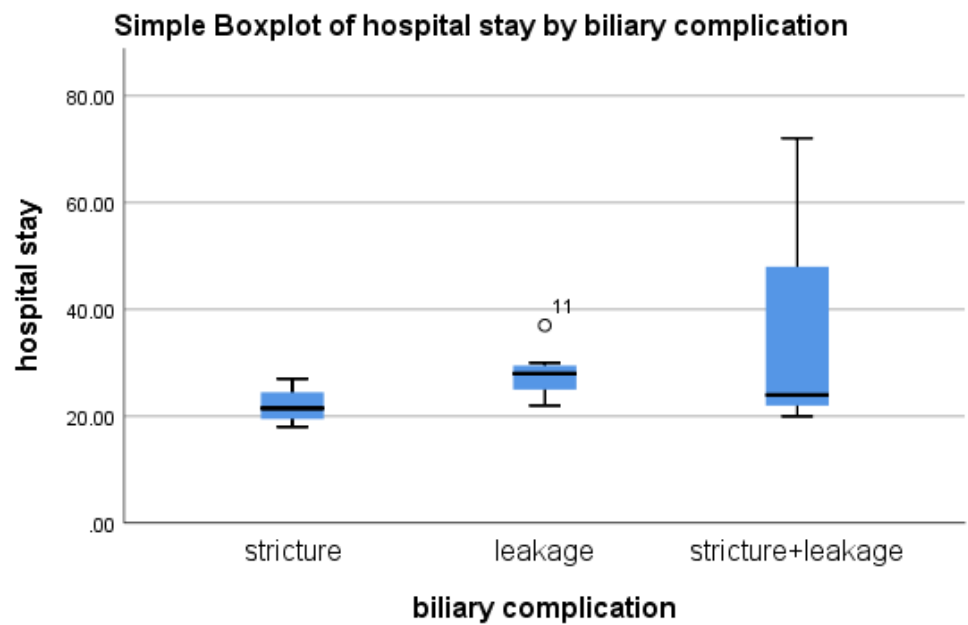

Figure 10 hospital stay in each intervention

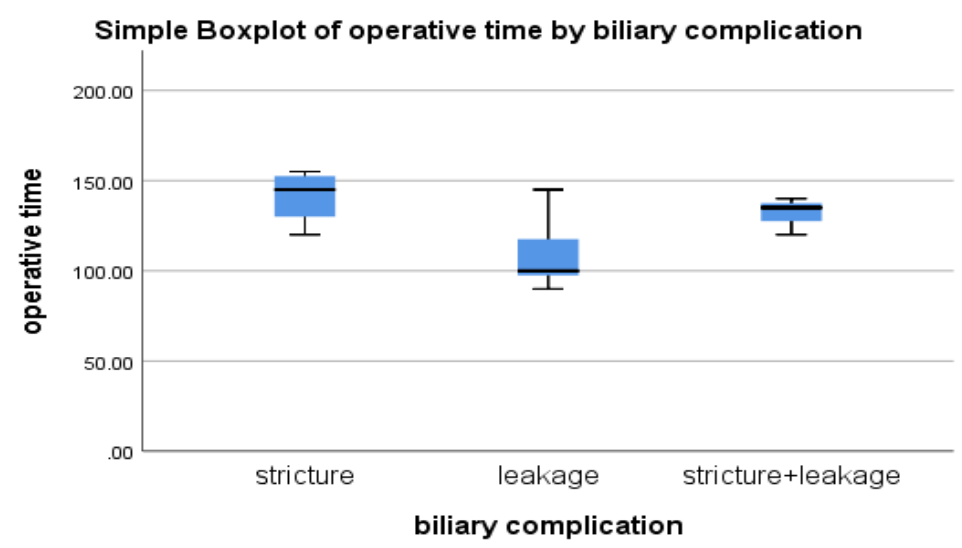

Figure 11 operative time in each complication 
Table 7 operative time and hospital stay in each surgical intervention

\begin{tabular}{|l|l|c|c|c|c|}
\hline & & $\begin{array}{c}\text { Drainage } \\
(4)\end{array}$ & $\begin{array}{c}\text { Hepaticojejuonstomy } \\
(9)\end{array}$ & $\begin{array}{c}\text { Repair + stenting } \\
(1)\end{array}$ & P value \\
\hline Operative time & mean \pm SD & $98.75 \pm 8.54$ & $136.67 \pm 12.75$ & 100 & $<0.001$ \\
\hline Hospital stay & mean \pm SD & $26.5 \pm 3.70$ & $28.56 \pm 16.61$ & 37 & 0.809 \\
\hline
\end{tabular}

Simple Scatter with Fit Line of operative time by surgical intervention

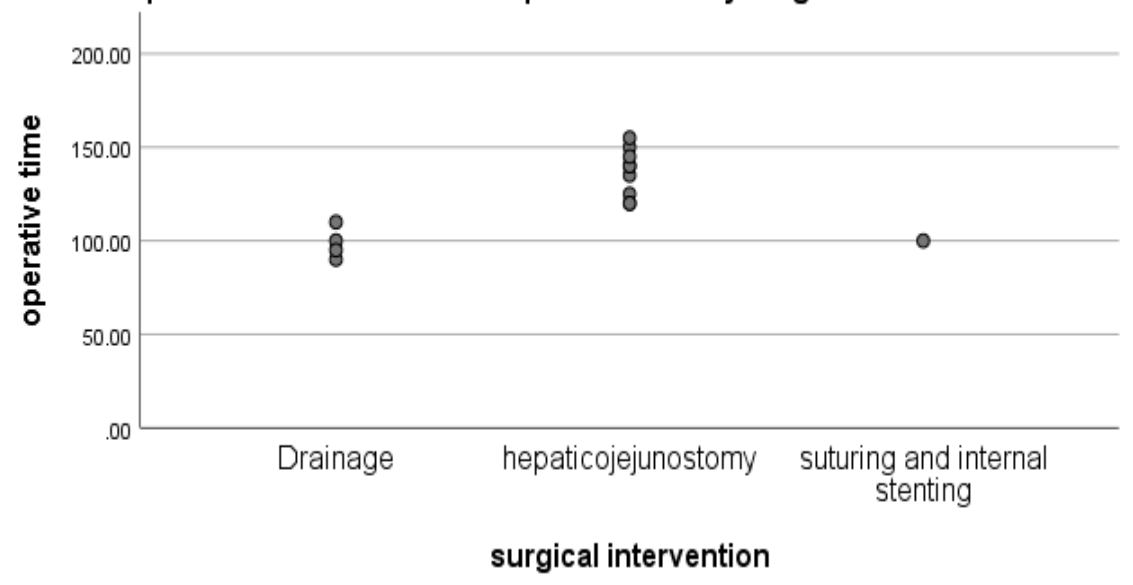

Figure 12 operative time in each surgical intervention

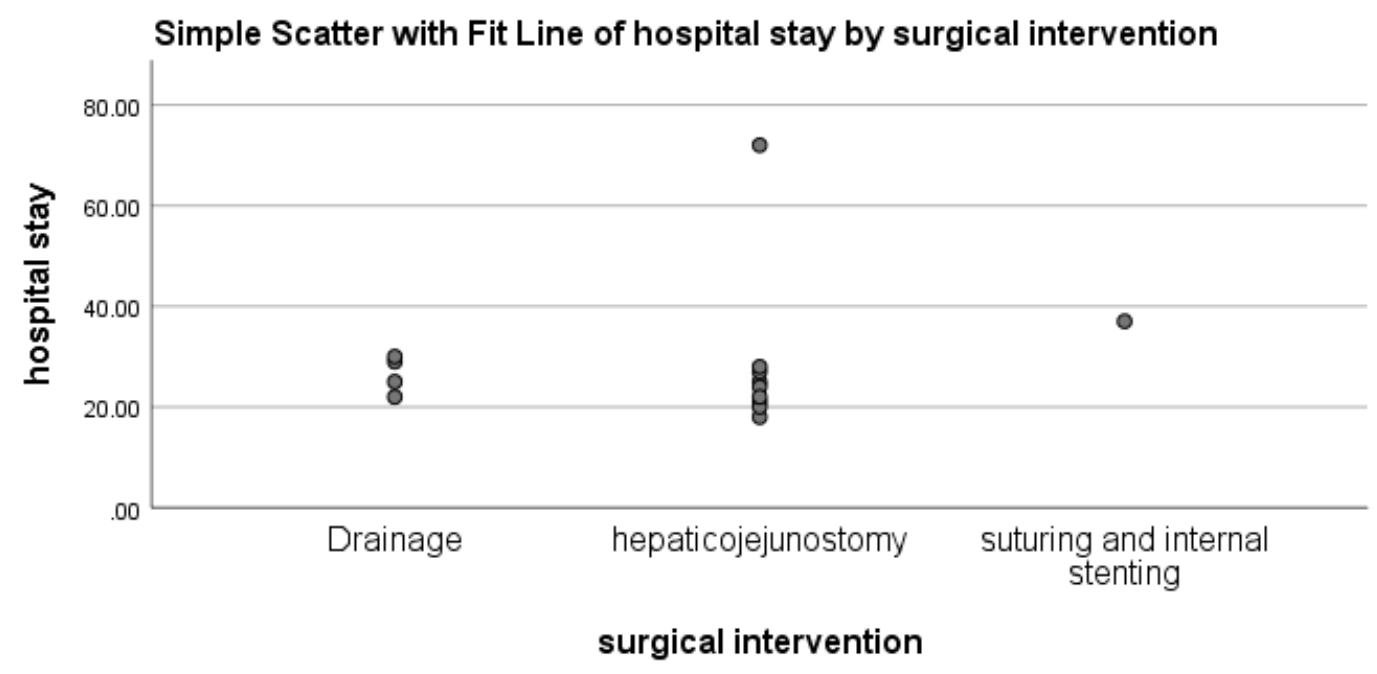

Figure 13 hospital stay in each surgical intervention 
Table 8 operative and post operative data

\begin{tabular}{|l|c|}
\hline Variable & Outcome \\
\hline Operative time (min) & \\
\hline mean \pm SD & $123.21 \pm 21.63$ \\
\hline Range & $90-150$ \\
\hline Hospital stay (day) & $28.57 \pm 13.41$ \\
\hline mean \pm SD & $18-72$ \\
\hline Range & \\
\hline Recurrent biliary complication & $2(14.29 \%)$ \\
\hline Yes & $12(85.71 \%)$ \\
\hline No & \\
\hline Mortality & $1(7.14 \%)$ \\
\hline Yes & $13(92.86 \%)$ \\
\hline No & \\
\hline
\end{tabular}

Table 8 shows operative and post-operative data.

\section{DISCUSSION:}

In a study by Hwang $\mathbf{S}$ et al BC have been a major source of morbidity and graft failure with a reported high incidence of (12-40\%). Many risk factors have been identified to contribute to such high incidence including multiple duct anastomoses, duct diameter $<4 \mathrm{~mm}$, and small unrecognized bile ducts ${ }^{[7]}$. In our center the biliary complications incidence was $11.84 \%$.

The clinical presentation of $\mathrm{BC}$ varies from slightly abnormal liver function tests to life-threatening biliary sepsis; however, most patients present with early leaks and/or strictures. The majority of strictures are anastomotic (90\%) rather than nonanastomotic strictures. ${ }^{[8]}$

Early diagnosis and appropriate multidisciplinary management approach is crucial to avoid graft dysfunction, lifethreatening sepsis, and graft or patient loss. A combination of several diagnostic tools might be necessary to provide accurate assessment of the biliary problem; some investigations are non-invasive as US, CT and MRCP, while others are more invasive like ERCP and PTC. Most centers would usually resort to conservative non-surgical strategy as the first choice in managing BC after LDLT. In a study by Kato $\mathbf{H}$ et al Non-surgical measures are primarily endoscopic retrograde procedures and percutaneous trans hepatic procedures; the use of endoscopic procedures has shown success rates around (40-70\%). In our center the success rate of non-surgical management for biliary complications was $68.9 \%$. ${ }^{[9]}$

Most centers prefer to use endoscopic retrograde procedures as the first line of management and reserve percutaneous transhepatic procedure to those patients who failed endoscopic management or those patients who had Hepaticojejunostomy. ${ }^{[10]}$

It is important to emphasize that the success rates after endoscopic and percutaneous manipulations vary significantly between different liver transplant programs depending on the institutional field strengths and expertise; some centers report success rates as high as $100 \%$ while others, including our center, have much inferior success rates with non-surgical approaches. [10]

Surgical reconstruction of $\mathrm{BC}$ following LDLT is usually the last resort after the failure of all conservative non-surgical measures. ${ }^{[11]}$

The reluctance to surgically manage BC followed by LDLT is owed to many predicted technical difficulties such as the presence of dense adhesions around the bare cut surface, small proximal intrahepatic 
ducts, which are often difficult to identity, presence of more than one duct with the need for multiple anastomoses, and fear of damage to precious vascular structures. Therefore, because of the above-mentioned reasons, most centers would adopt long-term conservative strategy rather than early consideration of surgical reconstruction for treating such complications; this nonsurgical approach usually involves repeated endoscopic and percutaneous procedures necessitating multiple hospital admissions and prolonged hospital stay. Despite this widespread reluctance to perform early surgical revision, there are many reports confirming that surgical revision is feasible in most cases with excellent long-term outcomes. ${ }^{[12]}$

In our experience, surgical revision was feasible in most of the operated cases and has significantly reduced the need for hospital admissions and invasive procedures. it significantly improved the patient's quality of life by reducing morbidities and hospital admissions. Moreover, both the decrease in hospital admissions and the reduction in the number of invasive procedures are both associated with potential cost savings and reduced resource utilization and saving the graft.

There are few reports in the literature in the setting of OLT. The initial experience by Davidson et al reported $20 \%$ morbidity and $6 \%$ mortality. ${ }^{[13]}$ However, more recent reports by Langer et al show less morbidity (16\% to $18 \%$ ), and no mortality. ${ }^{[14]}$ In our study the morbidity was $14.29 \%$ and the mortality was $7.14 \%$.

In our study there was 14 patients with biliary complications that was managed surgically. 4 patients with stricture, 7 patients with leakage and 3 patients with stricture and leakage. 3 patients were managed surgically from the start and the other 11 patients had non successful non operative managements.
Nine patients underwent redo hepaticojejuonstomy, four patients underwent only surgical drainage and one patient underwent primary suturing and internal stenting.

There were only two patients $(14.29 \%)$ who encountered recurrence of the biliary complications after surgery and one patient (7.14\%) who died after surgery by ARDS.

As the surgical management was the last resort in managing biliary complications, our study sample was limited

\section{Conclusion:}

Non-surgical measures are the primary treatment option for post transplantation biliary complications, but surgical management is the definite management for refractory cases with less hospital stay and recurrent admissions.

\section{REFERENCES:}

1. Busuttil RW, Farmer DG, Yersiz H, Hiatt JR, Mc Diarmid SV, Goldstein LI, Saab S, Han S, Durazo F, Weaver M, et al. Analysis of long-term outcomes of 3200 liver transplantations over two decades: a singlecenter experience. Ann Surg. 2005; 241:905-916; discussion 916-918.

2. Amesur NB, Zajko AB: Interventional radiology in liver transplantation. Liver Transpl 2006; 12:330-351.

3. Meirelles RF, Júnior, Salvalaggio $P$, Rezende De MB, Evangelista AS, Guardia Della B, Matielo CEL. Liver transplantation history, outcomes and perspectives. Einstein (Sao Paulo) 2015;13(1):149-152.

4. Thethy S, ThomsonBNj, Pleass H, Wigmore SJ, Madhavan K, Akyol M, Forsythe JL, James Garden O. Management of biliary tract complications after orthotopic liver transplantation. Clin Transplant. 2004; 18:647-653

5. Londono MC, Balderramo D, Cardenas A. Management of biliary complications after orthotopic liver transplantation: the role of endoscopy. World J Gastroenterol. 2008; 14:493-497. 
6. Perrakis A, Fortsch T, Schellerer V, Hohenberger W, Muller V. Biliary tract complications after orthotopic liver transplantation: still the "Achilles heel"? Transplantation proceedings 2010; 42:415457

7. Hwang S, Lee SG, Sung KB et al. Longterm incidence, risk factors, and management of biliary complications after adult living donor liver transplantation. Liver Transpl 2006: 12: 831.

8. Lee HW, Suh KS, Shin WY et al. Classification and prognosis of intrahepatic biliary stricture after liver transplantation. Liver Transpl 2007: 13: 1736.

9. Kato $\mathrm{H}$, Kawamoto $\mathrm{H}$, Tsutsumi $\mathrm{K}$ et al. Long-term outcomes of endoscopic management for biliary strictures after living donor liver transplantation with ductto-duct reconstruction. Transpl Int 2009: 22: 914.

10. Kim ES, Lee BJ, Won JY, Choi JY, Lee DK. Percuta- neous transhepatic biliary drainage may serve as a suc- cessful rescue procedure in failed cases of endoscopic therapy for a post-living donor liver transplantation biliary stricture. Gastrointest Endosc 2009: 69: 38.

11. Mita A, Hashikura Y, Masuda $Y$ et al. Nonsurgical policy for treatment of bilioenteric anastomotic stricture after living donor liver transplantation. Transpl Int 2008: 21: 320.

12. Chan SC, Fan ST. Biliary complications in liver trans- plantation. Hepatol Int 2008: 2: 399.

13. Davidson BR, Rai R, Nandy A, et al: Results of choledocojejunostomy in the treatment of biliary complications after liver transplantation en the era of nonsurgical therapies. Liver Transpl 6:201, 2000.

14. Langer FB, Györi GP, Pokorny H, et al: Outcome of hepaticojejunostomy for biliary tract obstruction after liver transplantation. Clin Transpl 23:361, 2009. 


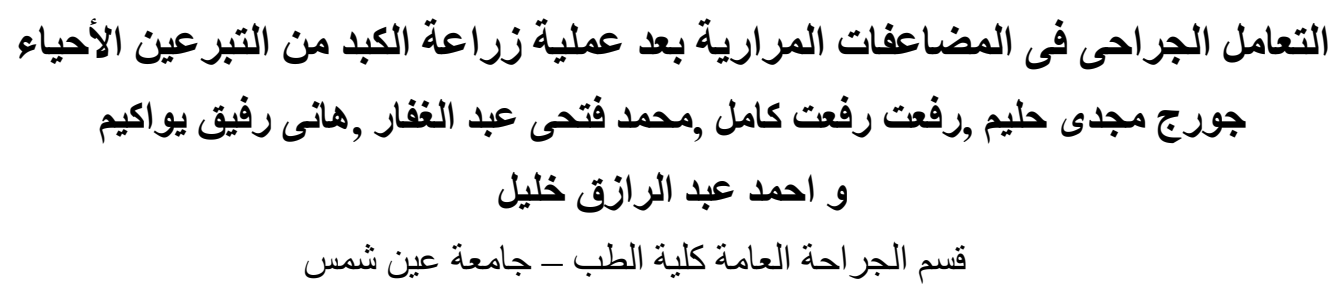

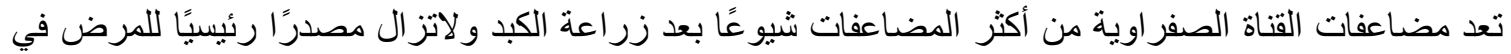

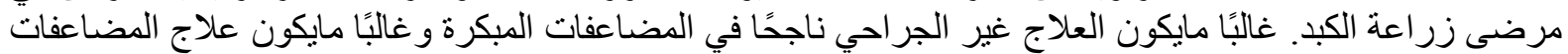

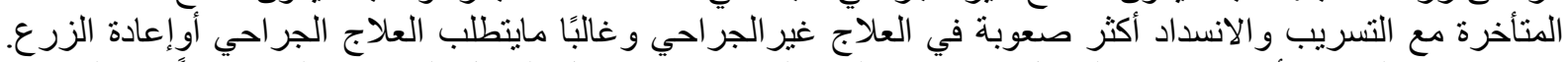

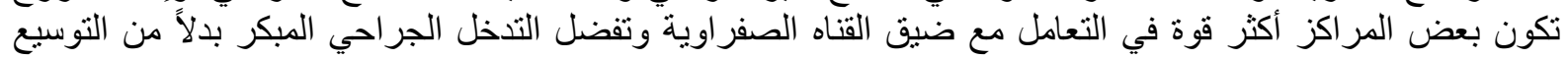
بالمنظار.

الهُف من هذه الدر اسة هو مناقشة العلاجات الجراحية لمضاعفات مابعد الزرع ونتائجة الجها ومعدل النجاح مع أوبدون تدخلا تغير جر احية سابقة في متابعة مابعد الجر احة.

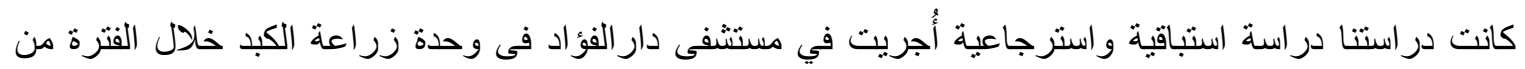

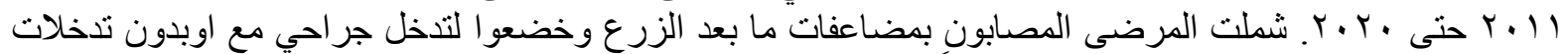

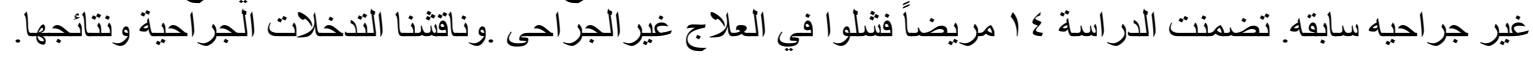

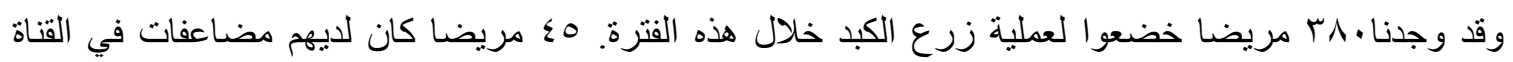

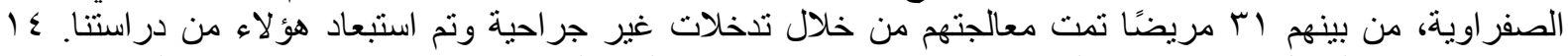

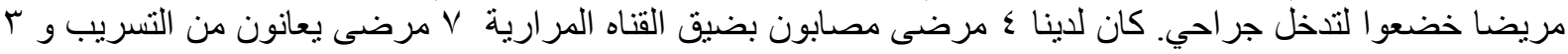

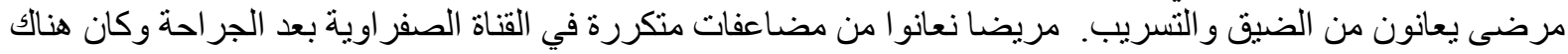
حالة وفاة واحدة فقط.

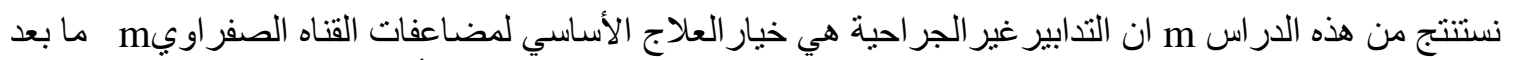
زر اعة الكبد،ولكن التنخلات الجراحية هي العلاج الامثل للحالات المستعصيس هير العع إقامة أقل في المستشفى وحالات دخول متكررة. 